\title{
THE NEEDS OF THE NATIVE FARMER IN THE TROPICS AND THE RAISING OF HIS LEVEL OF LIVING $\left.)^{\prime}\right)$
}

\author{
L. H. HUIZENGA \\ Division of Rural Economy of the Tropics, Agricultural University, \\ Wageningen, Holland
}

\begin{abstract}
Indeed welfare is essentially subjective even though many of its components are of material origin. It is a state of mind which is the product of a wide variety of physical and mental impressions (FAO - Essentials of Rural Welfare, 1949, p. 2).
\end{abstract}

\section{INTRODUCTORY}

There is no doubt that viewed in its totality human welfare is a complex matter. A great deal of a man's affairs in life consists of imponderables resulting from differences in the individual estimate of physical and spiritual needs. It is not true to say that the same income can be equated with the same welfare, even when the persons concemed are from each other's immediate vicinity. Nor does twice as much income mean twice as much welfare, since the latter is far too closely bound up with one's own ego, with personal assessments.

I have begun by stressing the complex nature of welfare because in the observations that follow I shall be obliged to confine myself to making more general comparisons between such welfare components as can be quantitatively expressed ${ }^{3}$ ). But what this limitation actually amounts to is that efforts to increase welfare are again reduced to the asquisition of a larger income. The latter should therefore be regarded as an important basic condition of the first, at any rate up to a certain level. This is esspecially true of the native cultivator in the tropics who hitherto has still often been unable to make reasonable provision for the primary physical needs of food and shelter (clothing, accommodation, etc.). But if we desire to improve this state of affairs we shall be obliged, even at this level, to provide simultaneously a satisfactory assimilation in the social sense.

The raising of the level of living of the native farmer in the tropics is a problem in which the complex of needs must occupy a central position. An understanding of the complex of needs is particularly necessary if we are to practise development techniques in a responsible fashion. Close mutual relationships exist between needs and the raising of the level of living. The approach to the problem of raising the level of living has certain consequences with respect to the poiicy to be adopted, and these must be fully realised beforehand. It is to these consequences in particular that I should like to draw attention. First, however, I will make clear what is meant by the terms "needs" and "level of living".

1) This article is based on a lecture given on November 18, 1958, at the Tropical Agricultural Days held in Wageningen on November 18 and 19, 1958.

2) Received for publication December 23, 1958.

3) For example, a comparison of the average consumption pattern at different income levels (ignoring individual divergencies from the mean). 


\section{TeRMS}

By "needs" I mean the entire complex of material and non-material requirements which man makes with respect to his physical and spiritual welfare. In this connection it will always be found that man has been able to supply a part of these needs, but another part, whatever the reason may be, he has been unable to satisfy. These unsatisfied needs (what is felt as a welfare shortage) may be regarded as needs in the narrower sense.

Nowadays the level of living is being more and more regarded as relating to present living conditions $(1)^{4}$ ), i.e. to the welfare level that has been achieved. A further distinction is made between the terms "standard of living" and "norm of living"; of these only the former is important here. The standard of living is regarded as the level of living, to which one's own desires or expectations aspire, in other words the level of welfare one desires to achieve or regain oneself, or which one regards as fitting and good for oneself to enjoy. Hence the difference between the standard of living and the level of living actually corresponds to what is felt as a welfare shortage.

Certain needs or components of the level of living (happiness in one's work, domestic bliss, acclimatization, feeling of safety, facilities for self-expression, etc.) cannot be quantitatively expressed, whereas others can (e.g. size of income, calorie intake, living space, provision of education, medical and hygienic facilities, etc.). The former components are of a more subjective, and the latter of a more objective and palpable kind. It is only the palpable, viz. the statistically measurable components that afford possibilities of comparison, and also in a wider context provided the effect of local factors can be satisfactorily inferred. An insight into the direction which palpable needs take may be obtained by comparing the manner of expending income as it increases. This is best illustrated by a few examples.

\section{METHOD OF CLASSIFYING CONSUMPTION EXPENDITURE}

Table 1 below gives a summary of the percentage distribution of expenditure over six different main items of consumption of families in Java (respectively wage-earning families working on estates and living away from home (2) and families of municipal workers at Jakarta (3)), in Ghana (wage-earning families at Accra (4)) and in the Netherland's (families of manual and black-coated workers (5)). Of each group two sub-groups were selected in which the size of the consumption expenditure showed a relatively great difference (about three times as large).

Of the four lowest expenditure groups, the families working on the estates in Java often failed to reach the level of reasonable provision of the primary bodily needs, while those in Jakarta and Ghana (Accra) just managed to reach it. The families in the Netherlands were presumably somewhat better off materially than the other two groups. A comparison of the lowest and highest expenditure groups in pairs as regards the percentage distribution of expenditure over the six different main items of consumption shows that the relative importance of expenditure "food" and "fuel, light and water" was always smallest in the highest expenditure group. On the other hand there were always higher per-

4) Numbers in brackets refer to bibliographic references at the end. 
Table 1.

\begin{tabular}{|c|c|c|c|c|c|c|c|c|}
\hline \multirow{3}{*}{ Main items of consumption } & \multicolumn{8}{|c|}{ In $\%$ of the total consumption expenditure } \\
\hline & \multicolumn{4}{|c|}{ Java } & \multirow{2}{*}{\multicolumn{2}{|c|}{ Ghana }} & \multirow{2}{*}{\multicolumn{2}{|c|}{ Netherlands }} \\
\hline & \multicolumn{2}{|c|}{ estates } & \multicolumn{2}{|c|}{ Jakarta } & & & & \\
\hline 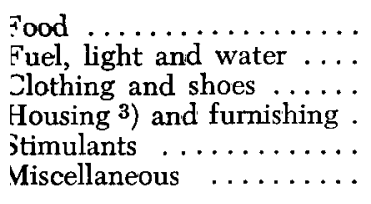 & $\begin{array}{r}75.0 \\
8.0 \\
2.7 \\
0.5 \\
6.0 \\
7.7\end{array}$ & $\begin{array}{r}58.3 \\
7.6 \\
7.6 \\
3.5 \\
6.7 \\
16.4\end{array}$ & $\begin{array}{r}60.5 \\
7.9 \\
5.9 \\
15.2 \\
3.9 \\
6.5\end{array}$ & $\begin{array}{r}51.8 \\
7.4 \\
9.0 \\
14.9 \\
2.9 \\
13.9\end{array}$ & $\begin{array}{l}58.9 \\
5.5^{11} \\
13.9 \\
10.6 \\
\left.3.4^{4}\right) \\
7.7\end{array}$ & $\begin{array}{l}53.7 \\
\left.4.2^{1}\right) \\
10.1 \\
8.2 \\
\left.12.1^{4}\right) \\
11.7\end{array}$ & $\begin{array}{l}39.3 \\
6.7^{1)} \\
\left.11.6^{2}\right) \\
13.8 \\
3.1 \\
25.4\end{array}$ & $\begin{array}{l}19.7 \\
3.51) \\
\left.12.8^{2}\right) \\
12.5 \\
1.9 \\
49.7\end{array}$ \\
\hline Гotal $\ldots \ldots \ldots \ldots \ldots$ & 100 & 100 & 100 & 100 & 100 & 100 & 100 & 100 \\
\hline $\begin{array}{l}\text { Average consumption ex- } \\
\text { penditure per family per } \\
\text { month } \ldots \ldots \ldots \ldots \ldots \ldots\end{array}$ & $f 5,49$ & $f 16,12$ & $f 10,24$ & $f 31,67$ & sh. 167 & sh. 480 & $f 239,67$ & $f 778,58$ \\
\hline Average number in family & 4.85 & 5.50 & 4.28 & 5.60 & 3.20 & 5.14 & 2.8 & 4.5 \\
\hline $\begin{array}{l}\text { Number of families } \\
\text { observed ........... }\end{array}$ & 696 & 159 & 57 & 10 & 46 & 21 & 103 & 166 \\
\hline Year of investigation & \multicolumn{2}{|c|}{$1939-40$} & \multicolumn{2}{|c|}{1937} & \multicolumn{2}{|c|}{1953} & \multicolumn{2}{|c|}{1951} \\
\hline
\end{tabular}

1) Excluding water.

2). Expenditure on cleaning accommodation and clothing are equally distributed over the main items "clothing" and "housing".

3) Of which house-rent in the 8 columns was respectively $-, 0.9,14.9,14.2,7.9,4.6$, 7.3 and $5.2 \%$ (inc. rates in the case of Ghana and water in the case of the Netherlands).

4) Inc. alcoholic beverages.

centages for "miscellaneous" and "furnishing" 5). In evaluating the differences in size between the corresponding percentages one should take into account the fact that the differences in welfare level between the lowest and highest expenditure groups were relatively smaller than the differences in size of the consumption expenditure because the families in the highest expenditure groups were considerably larger than in the lowest expenditure groups. Apart from this the size of the percentages is influenced by differences in local conditions (town - country, tropical climate - temperate climate, etc.) and in the local price relations between the six different groups of commodities and services.

The shifts which can be noticed above in the mutual retlationships between expenditure on the six different main items of consumption as expenditure increases do not distinctly occur until the level of a reasonable provision of the primary necessities has been exceeded. So long as this „minimum subsistence level" has not been reached the expenses concerned are more or less equally balanced ( 2 and 6). Expenditure on "food" then occupies a predominant place in rural tropical areas in particular (about $60-75 \%$ of the total expenditure on consumption ${ }^{6}$ ). The fact that below a particular subsistence level the relative importance of expenditure on the six different main items of soncumption remains substantially the same does not imply that there are no shifts in the

5) In the 8 columns respectively $0.5,2.6,0.3,0.7,2.7,3.6,6.5$ and $7.3 \%$.

6) Where this rural district is so linked to the home trade system that it is able to make a choice out of a sufficiently wide assortment of articles of consumption and staple products for the purpose of subsistence. 
relationships between expenses on subdivisions within these six main items. On Java, for example, the gradual change-over from the consumption of maize and/or cassava to rice begins at a very low subsistence level in districts where rice, maize and/or cassava are the staple diet (2). The same is true of betel chewing and smoking in this region, where the expenditure on smoking demands a steadily increasing percentages of the total expenditure on "stimulants". The fact that despite these shifts within the six different main items of consumption, below a certain minimum subsistence level the total amounts spent on these main items still remain at practically the same ratio to each other would indicate that the struggle for a reasonable supply of primary needs is manifested to virtually the same degree with respect to these six main items at every subsistence level below this minimum. Above this "minimum subsistence level" a change occurs. In an absolute sense expenditure on each of the six main items continues to rise as consumption expenditure increases, but the rate of increase is now different in the six main items. It is particularly expenditure on "miscellaneous" that increases in relative importance. The amounts spent under this main heading differ widely in character. Whereas expenditure on the other main items is increasingly directed to the purchase of "'more", "better" and/or "dearer" commodities as consumption expenditure increases, expenditure on "miscellaneous" now introduces also entirely new or different elements, including those of a social and cultural character. It is for this reason that I should like to enlarge somewhat on the subject of expenditure on "miscellaneous".

Table 2 below gives a survey of the distribution of expenditure under the heading "miscellaneous". The Ghana families are not included in this survey because the details relating to this group have not been published.

Table 2.

\begin{tabular}{|c|c|c|c|c|c|c|}
\hline \multirow{4}{*}{ Item of consumption } & \multicolumn{6}{|c|}{ As a $\%$ of the total consumption expenditure } \\
\hline & \multicolumn{4}{|c|}{ Java } & \multirow{2}{*}{\multicolumn{2}{|c|}{ Netherlands }} \\
\hline & \multicolumn{2}{|c|}{ estates } & \multicolumn{2}{|c|}{ Jakarta } & & \\
\hline & 0.4 & 1.1 & 0.5 & 1.3 & 4.0 & 4.5 \\
\hline Education and training $\ldots \ldots \ldots \ldots$ & 0.2 & 1.1 & 0.2 & 4.3 & 0.5 & 2.2 \\
\hline Transport $\ldots \ldots \ldots \ldots \ldots \ldots$ & 0.5 & 2.0 & 0.8 & 0.5 & 31 & \\
\hline Mail and correspondence ......... & 0.0 & 0.1 & & & 3.1 & 4.4 \\
\hline Development, recreation, social and & & & & & & \\
\hline political interests $\ldots \ldots \ldots \ldots \ldots \ldots$ & 0.0 & 0.1 & & & 3.9 & 5.4 \\
\hline Reading matter $\ldots \ldots \ldots \ldots \ldots \ldots$ & - & - & & & 1.5 & 1.6 \\
\hline Domestic help ............ & 0.0 & 0.2 & & & 0.1 & 3.0 \\
\hline Plants and animals ........... & - & 0.1 & & & 0.4 & 0.7 \\
\hline Insurances $\ldots \ldots \ldots \ldots \ldots \ldots \ldots$ & est. $\left.{ }^{1}\right)$ & est. & & & 3.7 & 6.2 \\
\hline Taxes $\ldots \ldots \ldots \ldots \ldots \ldots \ldots \ldots$ & est. & est. & 3.3 & 4.0 & 2.9 & 15.0 \\
\hline Religion and charity ........ & 5.6 & 7. & 0.7 & 1.7 & & \\
\hline Social obligations $\ldots \ldots \ldots \ldots$ & 0.5 & 2.7 & & & & \\
\hline Support of family & 0.2 & 0.9 & 0.5 & 1.3 & & \\
\hline Religion $\ldots \ldots \ldots$ & & & & & 1.1 & 0.9 \\
\hline Charity, gifts $\ldots \ldots \ldots \ldots$ & & & & & 1.5 & 4.4 \\
\hline Others $\ldots \ldots \ldots \ldots \ldots \ldots \ldots$ & 0.2 & 0.2 & 0.6 & 0.8 & 2.7 & 1.4 \\
\hline 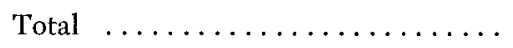 & 7.7 & 16.4 & 6.5 & 13.9 & 25.4 & 49.7 \\
\hline $\begin{array}{l}\text { Average monthly expenditure in guil- } \\
\text { ders per family on "miscellaneous". }\end{array}$ & 0,42 & 2,65 & 0,67 & 4,40 & 60,92 & 386,58 \\
\hline
\end{tabular}

1) est. = deducted from wages by the estate in certain cases. 
The expenditure on "miscellaneous" by families in the villages of Java who obtain their income to a greater or lesser degree by working for a wage on the estates was chiefly of a religious and social kind. It was closely related to the traditional mutual attachment existing within the village and family circle in rural districts of Java, although there are places where the ties are not always so strong ${ }^{7}$ ). Thus in the lowest of the two different expenditure groups, $6.4 \%$ of the total consumption expenditure and $83 \%$ of the total expenditure on "miscellaneous" went on these social and religious items, and in the highest expenditure group $11.4 \%$ and $69 \%$ respectively. Other expenditure on "miscellaneous" below the above-mentioned "minimum subsistence level" were practically negligible; above this level it was primarily expenditure on "health and hygiene", "education and training" and "transport" that gradually increased in importance. In Jakarta the social and economic bonds existing between persons were much looser than in the rural districts of Iava. Relatively speaking, townspeople were living more next to each other than with each other. Expenditure on "religion and charity" and "social obligations" was not therefore such an important item in Jakarta (in the rural districts this expenditure largely consisted of money spent on "slametans" ${ }^{8}$ ) given by the consumer himself, or of contributions to "slametans" givens by others). Families were, however, supported in Jakarta to about the same extent as in the rural districts of Java. With the exception of income tax, other expenditure on "miscellaneous" in the lowest of the two expenditure groups selected was also unimportant at Jakarta. The highest expenditure group again spent considerably more in proportion on "health and hygiene" and "education and training". In the case of the latter item in particular the percentages differed relatively widely (respectively 0.2 and $4.3 \%$ of the total consumption expenditure). Expenditure on "miscellaneous" occupied a much more important place in the Netherlands than on Java. In the Netherlands, income was found to be transferred in the form of taxes. This only accounted for $2.9 \%$ of the total consumption expenditure in the lowest of the two expenditure groups selected, whereas the figure was as high as $15.0 \%$ on the total consumption expenditure in the highest group. Other amounts spent on "miscellaneous" were spread over several items of various types, expenditure again being relatively nearly always greatest in the highest expenditure group. In the lowest expenditure group there was little if any money was spent on school fees, educational annuities, domestic help, family support, telephone, sport and recreation, whereas such expenditure was fairly important in the highest expenditure group.

The order of priority of the statistically measurable needs can be determined from changes in the manner of spending income as the latter increases ${ }^{3}$ ).

7) This relatively great attachment to each other was reflected both in the size of expenditure on "religion and charity", "social obligations" and "support of family" shown in table 2, and inter alia the number of members and non-members included in the family (in the lowest and highest expenditure groups respectively 0.54 and 1.12 persons per family). Hence there was a certain transfer of income from the more to the less well-to-do ( 2 and 7 ).

8) Thanksgiving feasts.

9) In the case of families of native farmers on Java this order of priority of needs was practically the same as that of the said families of wage-earners working on estates. The former spent proportionately rather more on "housing", "religion and charity" and "social obligations". Presumably they had a somewhat greater attachment to each other within their own village circle (2). 
Foremost is a reasonable provision for primary necessities, of which the need of sufficient food is by far the most important. As soon as this is satisfied the emphasis shifts from supplying primary to supplying secondary needs. This shift of emphasis implies both a change as regards essential provision in the sense of "more", "better" and/or "dearer" (food, clothing, stimulans, etc.) and the provision of needs which previously hardly occurred, if at all (education of children, hygiene, transport, etc.). This process continues with a further increase in material welfare, but is becomes a more difficult task to determine the order of priority of needs owing to the constantly increasing range of items now regarded as necessary for the satisfaction of needs. It also becomes more difficult on account of the greater variety of "professional requirements" which then occurs.

Generally speaking, however, it is not so very difficult to ascertain the order of priority of the statistically measurable needs of the native farmer in the tropics. According to the available medical and other data, his material welfare is often still below the level of a reasonable provision of primary needs. Only a relatively small number are considerably above this level. As an approximation it may be provisionally stated that the material welfare of the native farmer in the tropics still largely moves between two levels of which the lowest gives a reasonable provision of primary necessities to the extent of about $30 \%$ and the highest to about $300 \%$. The type of welfare deficiency felt varies according to the height of the level. The type and size of the welfare deficiency felt are the forces to which welfare measures should be harnessed in the first instance. After we have ascertained what welfare level has already been reached we can determine the type of welfare deficiency felt from the needs which correspond to this level, at any rate insofar as they can all be quantitatively expressed. It is not so easy to determine the size of the welfare deficiency felt, viz. the difference in welfare level between what has been achieved and the extent of the corresponding needs.

\section{SIZE OF THE WELFARE DEFICIENCY FELT}

To obtain a more exact limitation of the size of the welfare deficiency felt it is necessary to question individuals regarding the wants they are conscious of in their existence. It is found that in practice this question is not so easy for people to answer. Men do not seem to be very conscious of what their aims are in increasing their own welfare. It is usually possible to observe a marked desire to maintain such welfare as one possesses and to which one has become accustomed, but the desire for "more" is not so readily expressed in concrete form. It was an exception when such a person as a fairly well-to-do African farmer in Northern Rhodesia with $\& 150$ in the bank could inform me that his object in increasing his income was to acquire successively a brick-built house and a tractor. He was well aware of the fact that it would take many years to accomplish these aims. An enquiry held in the United States showed that persons of various categories considered an increase in income of about $30 \%$ as sufficient to remove what was felt by them as a welfare deficiency (8). This would seem to be a likely percentage. How often we hear people in Holland say "'If I only had no taxes to pay I could lead a comfortable life and do what I have a mind to!" To my knowlegde such a percentage is not known in the 
tropics. I do know that on Java the reason often given for leaving one's native district is "not enough land" or "not enough to eat". If this circumstance had not occurred it is certain that no one would have decided take such a drastic step as is always implied by emigration or transmigration. An enquiry held among a number of farmers and other African workmen on the Niger Agricultural Project in Northern Nigeria showed that in the first instance their desires extended to the possession of a bicycle and at a somewhat later stage to a small wireless set as well. The persons concerned were able to supply heir primary needs fairly amply and a few of them had the benefit of some education (which explains the desire to own a wireless set). In Netherlands New Guinea a comparatively eager desire for change and progress has been auroused among the population by contact with the abundance of consumer and staple goods of the U.S. army during the second world war, but a enquiry held at Hollandia already proved that despite the local order of priority of needs there was no substantial difference from the needs felt a other places in the tropics, at any rate up to a level at which the primary needs could be amply satisfied (9). Although it is difficult to define with accuracy the size of the welfare deficiency felt, taking into account the variation existing therein, enquiries constantly showed that the nature and size of the conscious requirements was bound up with the level of living already achieved andt that they are less ambitious than we are sometimes apt to image. If we put the level of living achieved at 100 , then the individual's own conscious desire to increase such a level of living is directed to a level possibly averaging 125,150 or 175 . If in course of time he succeeds in reaching the latter level, new desires have been gradually awakened in the meantime which may extend to a level of 200 or 250 when the level achieved is 150 or 175 .

\section{RAISING THE LEVEL OF LIVING}

The level of living can be raised by measures which always keep within the sphere of conscious requirements, and by measures which from the outset extend beyond what is felt by the individual himself as consciously lacking in his life. Starting from an existing level of living of 100 , this would mean either measures enabling levels of living of say, 125,175 and 250 to be successively reached, or measures for increasing the level of living to, say, 250 in one stage. In the first instance one seeks to co-ordinate one's measures to the existing urge for a higher level of living, and it will occasionally be necessary to help people over difficult hurdles at certian times; in the second instance the aim is to impose on people something of which they have no conscious need at that moment. Both methods are to be met with in the tropics. For example, the first method was adopted by the agricultural extension service in the former Dutch East Indies. The transferring of Javanese farmers to Southern Sumatra on farms which could provide a reasonable level of primary needs can also be regarded as an example of this. The second method is found in such large-scale projects as the "paysannats" in the Belgian Congo and the Office du Niger in the French Sudan. Education pitched at too high a level as compared to economic reality, or a community development project which makes excessive demands (e.g. the Nimboran project in Netherlands New Guinea) may also be included in the second category. 
When it is asked which of the two methods is the best the answer is not easy to find. Both methods are nearly always employed under too divergent circumstances, so that it is hardly possible to make a simple comparison with what can be achieved with the same financial resources in the same period. I myself prefer a method which is permanently adapted to the welfare deficiency felt and naturally promotes the development of the individual's initiative and capacities. In practice this means that something is done with people, that their existing urge for a higher level of living is satisfied and this urge further stimulated by natural means. This does not alter the fact that circumstances may occur in which no other good alternative can be imagined than a method which goes beyond the initial needs from the outset. This means in practice that something is done for people, that they are forced to start working for a material subsistence level of which they are not yet conscious, in the hope that they eventually grow used to the higher level and afterwards desire it themselves and be capable of maintaining it. Both methods are best illustrated by means of a few examples taken from practice. For this purpose I have chosen five examples (in view of the limitations of space I shall be oblige to confine myself to the main outlines).

\section{Improved Farmers' Scheme in Northern Rhodesia}

In Northern Rhodesia the purchase and purchase price of the staple maize in the region bordering the Ndola-Livingstone railway line are controlled by the Government (Maize Control Board (6 and 10)). The purchase price is fixed annually on the basis of delivery alongside the railway. In 1953, 1954 and 1955 the price was $40 \mathrm{~s} .9 \mathrm{~d}$., 41s. and 40s. 3d. respectively per $200 \mathrm{lbs}$. net (excluding sack). These prices were paid in full to the European settler but only in part to the African farmer, who in the three said years received 13s. Iess per $200 \mathrm{lbs}$. on delivery to the national purchasing depots. Of this 13s., 5s. was charged to costs of transport to rail and handling, and 8s. was paid into the African Farming Improvement Fund. The Improved Farmers' Scheme was financed from the resultant fund. The object of the Improved Farmers' Scheme is to achieve better agricultural practices, emphasis being placed on better soil use. Farmers participating in the scheme conform to certain regulations regarding planting (crop rotation), fertilisation and erosion control, but enjoy certain financial benefits in the form of subsidies on the purchase of ox-carts and fertilisers, credit facilities and a bonus payment per acre. Membership of the Scheme is voluntary. For example, the farmer may test it for half of his land, or after a time he may resign from the Scheme and once again start cultivating maize only year after year, with all the consequences thereof. In this way room is left for self-education. Development is accordingly financed by the farmer himself ${ }^{10}$ ). The object is now to reach the stage at which this selffinancing is no longer regulated by the authorities by means of a deduction from the price of maize, but by the farmers themselves out of the full selling price. A similar method, in which the emphasis is laid on doing something

10) In addition to the above-mentioned stimuli, the financing of more general projects such as the construction of drinking ponds for cattle and contour ridges, and temporary grass lays for controlling erosion. 
together with the farmers, is to be found in the Peasant Farming Scheme in the eastern province of Northern Rhodesia and the Master Farmers' Scheme in Nyasaland.

\section{Produce Marketing Boards in West Africa}

The Produce Marketing Boards in West Africa are a continuation of the West African Produce Control Board which was set up in 1942 with the object of providing the United Kingdom with raw materials in time of war (6 and 11). At that time the WAPCB was given a legal monopoly with respect to the chief agricultural exports, e.g. cocoa, palm oil, palm kernels, groundnuts and cotton, which products were purchased at fixed prices on the basis of purchase prices fixed by the Ministry of Food in Great Britain. After the war it was decided in principle to continue the monopoly system of price and market control in peacetime and to adapt it to the particular needs of the production areas concerned. The necessary reorganisation led in 1947-49 to the establishment of separate PMB's for these areas. The main objectives of the PMB's are :

1 stabilisation of the producer's price ${ }^{11}$ );

2 promoting the economic development of the production areas concerned.

As regards the latter objective, the PMB's have been favoured by fortune. Thanks to the unprecediented rises in the world market prices of raw materials in the years immediately succeeding the second world war and during the war in Korea, it was possible to build up comparatively large financial reserves of which a considerable portion could be earmarked for development. The question is now, what would have happened if these financial reserves had not been created and producers had received the full price in a single payment? We may imagine that there would have been two risks, viz. wastage of income (expenditure at an income level with which one is still unfamiliar and which has yet to become part and parcel of one's life) and reduction of productive activity (slackening of effort due to ignorance of how to lay out such an increased income so as to obtain satisfaction). Both dangers are all the more real in that owing to the small size and the nature of the farms concerned, possibilities of investment in the productive sphere are limited from the individual point of view. By putting an adequate brake on excessive increases in income these dangers are avoided. The price stabilisation policy of the PMB's is to be regarded in this light; by limiting fluctuations in income they promote effective income spending and optimum productive efforts. Áreover the trend of world market prices for the PMB's in the first years of their existence was such that adequate price stabilisation funds could be built up and it was also possible to provide the money for improving the basic or infra-structure of the production areas in question. In this case, as in the case of the Improved Farmers' Scheme in Northern Rhodesia, we can see that price and trade policy measures may constitute a means by which persons can finance their own development in a manner suited to the existing level of living and which satisfies their own immediate individual desires and possibilities of expansion.

11) Price deductions in the case of sharp price increases, price subsidies in the case of sharp falls in world market prices. 


\section{Paysannats in the Belgian Congo}

The main purpose of the paysannats ${ }^{12}$ ) is to raise the level of living of the rural population by improving agricultural practices (6). The authorities try to achieve this by means of a number of measures in which, to begin with, a particular family group is persuaded to parcel out in farms the land within their sphere of control; these farms are so arrannged that agriculture can be carried on under the supervision of officials of the administrative and agricultural departments according to INEAC regulations. By practising agriculture in the paysannat form the farmer is soon able to double or treble his income (13). The aim is to unite a large number of farmers into paysannats in a comparatively short time. This aim involves the establishment of an organisation on a national level in which any question of the scheme being carried out by voluntary efforts or under compulsion is overshadowed, at least for the time being, by the vast scale on which the scheme is being tackled. Hence a closer on the spot inspection of the manner of introducing the paysannats reminds one of an enlightened culture-system. Professor DE WILDE (Ghent) points out the dangers of this when he says of the position of the farmer in the paysannat that there is "compulsion instead of freedom, an object instead of a subject, and subordination instead of equality" (14). In the method described here certain tensions are unavoidable. They are felt by the farmer on whom there is, in fact, imposed a status and subsistence level which in many cases he is still not consciously aware of needing. The tensions also arise among the INEAC, the administration and agricultural departments, among the planning and executive authorities, the chief reason being that too little attention is still given to the social and economic survey within the whole framework of agricultural improvement schemes. This does not alter the fact that an ambitious attempt is being made in the Belgian Congo to give agriculture and the farmer an appropriate and well-found place in the country's economic structure. It is an attempt which must be viewed in the light of the alternative possibilities, and it is certainly justified if there is a reasonable hope of success in developing human possessions and desires to such an extent that what is now imposed will no longer be felt as such in the near future.

\section{Office du Niger in the French Sudan}

The work of the Office du Niger, established in 1932, is to develop, irrigate, colonise and work an area on the left bank of the Niger starting downstream from Sansanding (6 and 15). This is a fertile district, but owing to the scanty and fluctuating rainfall it was unsuitable for agriculture unless irrigated. It was decided to do this in 1929 after the various possibilities had been tested in a series of investigations from 1913 onward. In 1947 the barrage dam near Sansanding began operating and it was possible to start developing the area in question which was declared open state land. As regards the possibilities of attracting the necessary colonists, experiments undertaken in the period subsequent to 1924 had shown that it was best for them to be given the status

12) By paysannat is meant an organisation form of rural economy under which native family groups, assisted by the government, systematically render productive and work in a rational manner lands they will permanently settle (12). 
of farmer immediately and not that of temporary agricultural worker at the same level of income. The land is therefore granted at once to the head of the colonist family with hereditary right of use. Each colonist family is given an area of land of which the number of hectares is about equal to the number of persons in the family. The income to be derived from this land would be many times greater than the former average income. The grant is provisional and is made on acceptance of the condition of fulfilling obligations laid down by the Office du Niger with regard to efficient working. The chief of these obligations relates to membership of the Association Agricole Indigène. This AAI is the agricultural association of a colonisation centre and has the character of a compulsory co-operative. Its general purpose is to improve the territory of each of its members and facilitate working. The fact that the posts of head of the colonisation centre and director of the AAI are united in the same person emphasises the unity in administration and working. The entire organisation still bears the impress of a marked paternalism, since economic administration is not yet possible without strict government supervision. But the AAI has its educational value nonetheless, insomuch as the colonists become acquainted with a sound administration of their interests. Moreover they can occupy posts in this organisation which will broaden their mental horizon. In this manner, and with the aid of education and other suitable means, the Office du Niger aims at gradually developing an economically sound and vigorous farming community in the area developed, so that the farmers will eventually be able to organise efficiently their own interests and those of the community.

\section{Education of farmers in Netherlands New Gunea}

Agriculture in Netherlands New Guinea is still in the initial stage of development (16). The authorities are trying to raise this low level by such means as :

1 education of the farmer by means of agricultural training;

2 education of the farmer directly on his farm.

The first method envisages the education of selected youths from the villages who as "pioneer farmers" will have the task of raising the level of agriculture in their own vicinity. For this purpose practical agricultural courses were started at three places in Netherlands New Guinea in 1948-49. Two of these have since been discontinued. The remaining course at Seroei provides a two-year training for selected youths from the villages who have received three years village school education. These youths are accommodated in a boarding school belonging to the course where they receive instruction which partly consists of some theoretical knowledge ${ }^{13}$ ), but is mainly a practical schooling in the use of improved agricultural methods ${ }^{14}$ ). To date 20-25 trained pupils have been turned out each year, but most of them have not returned to their villages as more fully-fledged farmers but sought a paid post with the government or a private firm wherever they could find it. Moreover it could not be ascertained whether those who returned to the villages had a

13) About 500 lesson hours per annum.

14) Over 1500 hours per annum. 
favourable effect on the practice of agriculture in their villages. Hence this method has not hitherto come up to expectations. What had been learned could not, or at any rate not immediately, be reduced to practice in a fruitful manner. Various reasons have been adduced for this, but the main cause is that the realities of the situation have not been sufficiently allowed for. In Netherlands New Guinea there is still no deep-rooted farming community of a specific level, and no conscious desire to become a farmer - not to say a better farmer, and all the consequences thereof - a desire with which agricultural schooling can be successfully co-ordinated in a more or less strange environment.

Better results were obtained in Netherlands New Guinea by approaching the farmer directly on his farm. There have been noticeable achievements, for example, by the agricultural extension officer at Seroei. In a district in which the population mainly subsisted on sea-fishing, sago production and a small amount of crops grown for domestic consumption, this extension officer, by means of a personal approach which was adapted to the environment, succeeded in setting apart communal village land for the establishment of agricultural nuclei. Each agricultural nucleus comprises a larger or smaller number of adjacent farms on which agriculture is systematically developed. Any member of the village community, irrespective of whether he has land-holding rights, may start a farm in the agricultural nucleus provided he is willing to follow the directives of the agricultural extension service as regards the arrangement of and extensions to the farms. The cultivation of annual food crops continues to form a substantial part of the farm in the agricultural nuclei. A new perennial cash crop (cocoa) has in addition been introduced via the present system of intermittent land use by planting between the usual food crops. In August 1954 a start was made on the establishment of the first agricultural nucleus for 22 farmers. By the end of June 1958 there were already 16 agricultural nuclei with a total of 351 farmers. By that date the total area planted with cocoa was 218 hectares. A start has also been made on the introduction of coffee, nutmeg and livestock (cows and goats). A genuine farming community with its "better" and "inferior" farmers with larger and smaller farms is gradually being developed in the agricultural nuclei. People are beginning to leave the villages on their own initiative in order to settle in the agricultural nuclei. The division of labour within the family is changing; more and more heavy agricultural work is being done by the men ${ }^{15}$ ) and lighter work by the women. The total self-activities of the family have become much more numerous and productive. Adapting his methods to what is felt as a welfare deficiency and satisfying the interest displayed in novelties, the agricultural extension officer at Seroei has started a development which holds out much promise for the future and still has to be rounded off by creating, for example, a suitable organisation for the transport, processing and marketing of the cocoa produced.

The two methods discussed above are also instructive from the cost point of view. From 1955 to 1957 the courses in practical agriculture cost about $f 3.000$ per pupil trained (about $f 64.000$ per annum). In the period from

15) Cocoa (a novelty of which great hopes are held) has the active interest of men who regard work in the traditional native agricultural system as something inferior. 
August 1954 to June 1958 the total expenditure on direct assistance to the agricultural nuclei (wages of overseers, construction of nurseries, supply of plant material, etc.) was nearly $f 48.000$. During the same period the salaries and wages of staff of the agricultural extension service of the sub-district of Japen/Waropen totalled about $f 119.000$. A part of this amount can be charged to the agricultural nuclei. If half of this amount is thus charged we arrive at a total figure of about $f 300$ for each farmer with a higher or lower level of education. Seen against the background of the results achieved to date, these costs, although by no means complete in either case, give some idea of what can be achieved by both methods applied under specific local conditions.

\section{Conclusion}

The above observations have centred on the relationships between needs and the raising of the level of living. In order to determine what is the most effective strategy for raising the level of living we need an insight into the existing level of living and what is felt to be a welfare deficiency. The insufficient attention paid to this is the reason why in the past well-meant and sometimes ambitious attempts at raising the level of living of the native farmer in the tropics have frequently fallen below expectations. Of this it is also true to say "more haste less speed".

\section{REFERENCES}

1 UNO : Report on International Definition and Measurement of Standards and Levels of Living, New York, 1954.

2 Hutzenca, L. H. : Het koeliebudgetonderzoek op Java in 1939-40, Wageningen, 1958.

3 Centraal Kantoor voor de Statistiek: Een onderzoek naar de levenswijze der gemeentekoelies te Batavia in 1937, Batavia, 1939.

4 Office of the Government Statistician: 1953 Accra Survey of Household Budgets, Accra, 1953.

5 Centraal Bureau voor de Statistiek: Nationaal Budgetonderzoek 1951 (Samenvatting van de resultaten, serie $A$, no. 2), Zeist, 1957.

6 HaAs, J. H. DE and L. H. Huzenga: Rapport over een studiereis inzake landelijke ontwikkeling in Tropisch Afrika, Wageningen, 1957.

7 Huizenga, L. H. : Level of Living and Capital Formation, IIIe Symposium International d'Economie Rurale Tropicale, Paris, 1956.

8 Hoselitz, B. F. : The Progress of Underdeveloped Areas, Chicago, 1952.

9 Hurzenca, L. H.: Uitkomsten van een onderzoek naar de levensomstandigheden van 22 Papoea-gezinnen te Hollandia-Haven in juni-juli 1957, Wageningen, 1958.

10 Government of Northern Rhodesia: Annual Report of the Department of Agriculture for the year 1954, Lusaka, 1955.

11 Bauer, P. T. : West African Trade, Cambridge, 1954.

12 Ministerie van Koloniën: Tienjarenplan voor de economische en sociale ontwikkeling van Belgisch-Kongo, Brussel, 1949.

13 Pinxten, K. : De Inlandse Landbouwbedrijven in Belgisch-Kongo en Ruanda-Urundi, delen I en II, Brussel, 1954.

14 WILDE, L. O. J. DE : Lezingen over de opvoeding der plattelandsbevolking in BelgischKongo, Antwerpen, 1951.

15 Sprtz, G.: Sansanding (Les irrigations du Niger), Paris, 1949.

16 Hurzenga, L. H. : Beroepsvorming van de Papoea in Nederlands Nieuw-Guinea, Internationale Afrikaanse Studiedagen, Gent, 1957. 